\title{
Comparing KAP regarding Halal pharmaceuticals among general practitioners and hospital doctors
}

\author{
Saleha Sadeeqa, Azmi Sarriff \\ Discipline of Clinical Pharmacy, School of Pharmaceutical Science, Universiti Sains Malaysia, Penang Malaysia.
}

\begin{tabular}{|c|c|}
\hline ARTICLE INFO & ABSTRACT \\
\hline Article history: & \multirow{9}{*}{$\begin{array}{l}\text { There is an increasing awareness amongst Muslim consumers to avoid all items containing non-Halal ingredients } \\
\text { including medications. General practitioners and hospital doctors, in their practice encounter with the patients of } \\
\text { different severity of illness, and accordingly their exposure to different categories of medicines will also be } \\
\text { different. It therefore, needed for a study to compare knowledge, attitude and perception (KAP) of general } \\
\text { practitioners and hospital doctors regarding Halal pharmaceuticals. This was a cross-sectional study using a } \\
\text { structured, self-administered questionnaire to compare the knowledge, attitude and perception regarding Halal } \\
\text { pharmaceuticals, among general practitioners and doctors working in various government hospitals in Malaysia. } \\
\text { Results revealed that significant difference in the perception of general practitioners and hospital doctors was } \\
\text { found. Significant difference was also found in some of statements of knowledge and attitude. This is concluded } \\
\text { that general practitioners and hospital doctors differ in knowledge, attitude and perception regarding Halal } \\
\text { pharmaceuticals. P } \geq 0.05 \text { was taken as statistically significant. }\end{array}$} \\
\hline $15 / 08 / 2014$ & \\
\hline /08/2014 & \\
\hline $9 / 2014$ & \\
\hline Available online: $30 / 10 / 2014$ & \\
\hline Key words: & \\
\hline Knowledge, Attitude, & \\
\hline Perception, KAP, Halal, & \\
\hline pharmaceuticals & \\
\hline
\end{tabular}

\section{INTRODUCTION}

Halal is an Arabic word which means "lawful," "permissible" under Islamic law ((Khattak, et al., Nasaruddin, et al., Husain et al., 2012). The opposite of Halal is "Haram" which means "unlawful", "prohibited", "forbidden". The opposite of Halal is "Haram" which means "unlawful", "prohibited", "forbidden" (Riaz and Chaudry, 2004, MS: 1500, 2004). Halal and Haram are universal terms that apply to all facets of life. However, this study will adapt these terms to refer only to pharmaceutical products that are deemed permissible for consumption of Muslims. Halal is a well known word in the entire Muslim world. However as the Muslim population is expanding in other continents, this word has come to be used so commonly in the day to day life that even the non-islamic world has become cognizant of this terminology. This has resulted in Halal signs, at shops and food products, in America and Europe, catering for the religious beliefs and needs of the Muslim consumers. Medicines play a pivotal role in the process of human development as their rational use can decrease the morbidity and mortality and improves the quality of life (Cohen-Kohler, 2007).

\footnotetext{
* Corresponding Author

Email: salehasadeeqa@gmail.com
}

A drug/medicine is composed of a combination of active ingredients, and excipients. These substances are obtained from a variety of sources- animals, plants or synthetic origin (Geraldine et al., 2004, Hoesli \& Smith, 2011). In case of animal source, it may be porcine, dead animal or blood. All these are Haram/forbidden for Muslims as mentioned in the Holy Quran (Al-Quran, accessed on 2012 March 2). It is evident that, not only, consuming Halal food but also consuming Halal medication is important because it forms a major part and behavior of being a good practicing Muslim. It is pertinent to mention that all old religions of the world like Hinduism, Judaism and Christianity also command certain religious restrictions and bindings on their followers in the consumption of foods and drinks (Geraldine et al., 2004, Easterbrook \& Maddern, 2008). They may use other terminologies to define these restrictions but the main sentiment is the same. Therefore it would be pertinent to look into various items of human consumption, including medicines, and their variants, to determine admissibility according to individual beliefs. As majority of Malaysian population is Muslim (Statistics Malaysia, 2010), there are many government and non government organizations which are playing an active role to ensure provision of Halal foods and pharmaceuticals to Muslim consumers. 
General practitioners and hospital doctors, in their practice encounter with the patients of different severity of illness, and accordingly their exposure to different categories of medicines will also be different. To the best of our knowledge no study has been done so far to compare the knowledge, attitude and perception of general practitioners and hospital doctors regarding Halal pharmaceuticals. Therefore the main objective of this study is to compare levels of knowledge, attitude and perception among general practitioners and hospital doctors.

\section{METHODOLOGY}

\section{Type of study design}

A descriptive, cross-sectional study design was adopted for this research project by using structured, validated, selfadministered questionnaire. For general medical practitioners, a postal survey was conducted across Malaysia.

\section{Study location \& setting}

Study settings included various government hospitals across Malaysia and systematic randomly selected registered clinics in the country.

\section{Inclusion \& exclusion criteria}

General medical practitioners registered with Malaysian Medical Council and all medical doctors working in different departments (except those who were not involved in prescribing i.e. radiologists, pathologists etc;) in selected government hospitals, on duty during the study period and willing to participate in the study (Wong et al., 2013), were recruited as 'study participants'. Whereas those not registered with Malaysian Medical Council, or those who refused to give consent were excluded from this study.

\section{Sample size calculation}

A list of addresses of 6,442 clinics registered with Malaysian Medical Council was obtained from Ministry of Health, Malaysia. For general medical practitioners, a sample size of 545 was calculated by 'Raosoft online sample size calculator 'with a confidence level of $95 \%$ and margin of error $5 \%$ (McCrumGardner E, 2010). For doctors working in hospitals, convenience sampling technique was used. All doctors, involved in prescribing medicines, in selected hospitals, were contacted. In total, 482 doctors were recruited as participants.

\section{Study instrument}

After extensive literature review, a self administered questionnaire was designed to conduct this study. The questionnaire was validated by a panel of experts which was composed of eight (8) senior academic researchers in the field of pharmacy and was restructured according to their recommendations. Initially a pilot study was conducted to determine the reliability of the updated questionnaire. Cronbach's alpha was applied to test validity and internal consistency of the questionnaire (De Bourdeaudhuij, 2005). Final modifications were made based upon the results of pilot study. The final questionnaire consisted of four parts. The first part of the questionnaire was on respondents' demographic information including age, gender, race, religion, nationality, current position (general practitioner, medical officer, house officer or specialist/consultant), current area of practice, country of basic educational degree, basic medical qualification, postgraduate medical qualification, and finally the experience. Second part comprised of nine statements to evaluate the knowledge of respondents towards Halal pharmaceuticals. Third part consisted of 11 statements for appraising perception towards Halal pharmaceuticals and final part had nine statements about the attitude of respondents concerning Halal pharmaceuticals. All questions were close ended, except one at the end was open-ended question seeking the participants 'general comments'. For knowledge statements respondents were asked to choose "Yes" or "No" options. Affirmative answer (yes) was scored one (1) while negative answer (no) was scored zero. Hence the minimum and maximum score for knowledge could be 0 to 9 . A five point Likert scale was used for perception and attitude statements starting from "strongly agree" to "strongly disagree" , which was scored as; strongly agree $=5$, agree $=4$, neutral $=3$, disagree $=2$ and strongly disagree $=1$. Thus the minimum and maximum possible score for attitude and perception was; 1 to 45 , and 1 to 55, respectively. Total KAP score could be 109 .

\section{Data collection procedure}

For the distribution of questionnaires, survey research guidelines were followed. Systematic randomly selected clinics in Malaysia were included for sending questionnaires by post. Questionnaire along with explanatory statement and a return selfaddressed, postage paid envelope were sent to systematic randomly selected clinics. All questionnaires were sent by normal mail. Respondents were requested to return the questionnaire within 2 weeks. First reminder was sent to all selected clinics, excluding those who had responded and to those whose letters were returned due to closed clinics or changed addresses (Bjertnaes et al., 2007). A period of 2 weeks was again allowed for return of the questionnaires after the first reminder. A second reminder was sent to all non-responding clinics. Responses were collected upto15 days after the second reminder. After 6 weeks any further returned questionnaires were not included in the study. Explanatory statement and a return self-addressed, postage paid envelope were sent each time. Those questionnaires which were returned unopened and stamped on the envelope "addressee has moved" or 'closed clinics' were excluded from the calculation of response rate (Ismail and Abidin, 2009). To maximize the response rate, each mailed survey was accompanied by a cover letter stating the survey objectives, assuring confidentiality of the responses, agreeing to share the findings, giving the approximate time needed to complete the questionnaire and providing a preaddressed postage-paid return envelope (Rezaee and Burton, 1997). In government hospitals, doctors were approached through head of the departments (Oshikoya and Awobusuyi, 2009) and 
were requested to return the completed questionnaires within two weeks. Reminders were sent after one week (Desai et al., 2011). Respondents were assured for confidentiality of their personal information in the explanatory statement. No incentives were offered to any of the respondents (Lie and Boker, 2006). The completion of the questionnaire by respondents was taken as their consent to participate in the study.

\section{Data analysis}

After collecting questionnaires, data was entered in SPSS version 18. After data cleaning, normality of data was checked by Kolmogorov-Smirnov test (Pallant, 2011). Descriptive statistics (mean, standard deviation, frequency, percentage, median, inter quartile range) was applied to summarize the data (Tiralongo and Wallis, 2008). The Mann-Whitney U Test was applied to test for difference between general practitioners and hospital doctor's knowledge, attitude and perception (Pallant, 2011). $\mathrm{P} \geq 0.05$ was taken as statistically significant.

\section{RESULTS}

\section{Respondent's demographics}

A total of 407 respondents participated in the survey, and analysis was performed on all of 407 forms. Among general practitioners, a total of 164 replied with a response rate of $30 \%$. Whereas 243 doctors working in government hospitals participated in the study with a response rate of $50 \%$.

\section{Comparing knowledge regarding Halal pharmaceuticals among general practitioners and hospital doctors}

Comparison between general practitioners and hospital doctor's knowledge regarding Halal pharmaceuticals is depicted in Table-1 and Table-4. Results revealed that there is no significant difference in the level of knowledge (regarding Halal pharmaceuticals) between general practitioners $(\mathrm{Md}=8, \mathrm{n}=161)$ and hospital doctors $(\mathrm{Md}=6, \mathrm{n}=244), \mathrm{U}=, 19306.500, \mathrm{z}=-0.307$, $\mathrm{p}=.0 .759$

\section{Comparing regarding attitude Halal pharmaceuticals among general practitioners and hospital doctors}

Comparison between general practitioners and hospital doctor's attitude regarding Halal pharmaceuticals is depicted in Table-2 and Table-4. Results revealed that there is no significant difference in the level of attitude (regarding Halal pharmaceuticals) between general practitioners $(\mathrm{Md}=48, \mathrm{n}=162)$ and hospital doctors $(\mathrm{Md}=45, \mathrm{n}=244), \mathrm{U}=18808.500, \mathrm{z}=$ $0.827, \mathrm{p}=0.408$.

\section{Comparing perception regarding Halal pharmaceuticals among general medical practitioners and hospital doctors}

Comparison between general practitioners and hospital doctor's perception regarding Halal pharmaceuticals is depicted in Table-3 and Table-4. Results revealed that there is significant difference in the level of perception (regarding Halal pharmaceuticals) between general practitioners $(\mathrm{Md}=35, \mathrm{n}=162)$ and hospital doctors ( $\mathrm{Md}=34, \mathrm{n}=244), \mathrm{U}=, 16790.500, \mathrm{z}=$ $2.575, p=0.010$. The direction of the difference is towards general practitioners which have higher mean rank.

\section{DISCUSSION}

The study aimed to compare the knowledge, attitude and perception of general practitioners and hospital doctors on the issues surrounding Halal pharmaceuticals in Malaysia. Intensive literature review found no such study which is conducted to compare the knowledge, attitude and perception among general practitioners and hospital doctors. In the present age, medicines have become a necessity to maintain our health. Usually there are three players in this context; doctors, pharmacists and consumers. Consumers usually cannot decide which medicine is suitable for them. This is then the role of the doctors to choose the most suitable medication for his/her patient keeping in mind, the religious beliefs of the patient. This is an expected and undeniable finale that doctors are perceived as one of the most knowledgeable health care practitioners on drugs and medications. In fact, closer patient-doctor relationship has resulted in consumers to perceive that the advice of doctor is reliable. Hence, doctor's opinion becomes an important factor when it comes to the drug decision making process. This study tried to compare the knowledge of general practitioners and doctors working in hospitals, about Halal pharmaceuticals. Study showed that significant difference was found in some of knowledge statements while not in others. Significant difference was found in knowledge statement "Are you aware of the term/word "Halal pharmaceuticals" and the direction of difference was towards general practitioners, as they had higher mean rank. Significant difference in knowledge was also found in the statement "Do you know that it is ethical obligation for a practitioner to take consent from the patient before prescribing any medicine which has any non-Halal content", and the difference was in the direction of hospital doctors. Significant difference was not found in total knowledge score. Study further showed that significant difference was found in some statements of attitude while not in others. Significant difference was found in attitude statement "I discuss with patients about forbidden/Haram ingredients of drugs" and hospital doctors having higher mean rank. While general practitioners had higher rank in the statement "I consider patient's religious beliefs when designing a treatment regimen". Furthermore, significant difference was found in attitude statement "I prefer Halal medicines in my practice" and general practitioners had higher rank. General practitioners also had higher rank in the statement "I recommend the purchase of Halal alternatives, which may be more expensive". Significant difference was not found in total attitude score. Study further found that significant difference was found in total perception score among general practitioners and hospital doctors and the direction of difference was towards general practitioners, getting higher mean rank. 
Table 1: Comparing knowledge among general practioners and hospital doctors

\begin{tabular}{|c|c|c|c|c|c|c|c|}
\hline Statements & Position & $\mathbf{N}$ & $\begin{array}{l}\text { Mean } \\
\text { Rank }\end{array}$ & $\begin{array}{l}\text { Sum of } \\
\text { Ranks }\end{array}$ & $\begin{array}{c}\text { Mann- } \\
\text { Whitney U }\end{array}$ & $\mathbf{Z}$ & $\mathbf{p}$ \\
\hline \multirow[t]{2}{*}{ Are you aware of the term/ word "Halal"? } & General practioner & 161 & 201.49 & 32440.00 & & & \\
\hline & Hospital doctor & 243 & 203.17 & 49370.00 & 19399.000 & -.950 & .342 \\
\hline \multirow[t]{2}{*}{ Are you aware of the term/word "Haram"? } & General practioner & 161 & 204.96 & 32999.00 & 19165.000 & -.827 & .408 \\
\hline & Hospital doctor & 243 & 200.87 & 48811.00 & & & \\
\hline \multirow[t]{2}{*}{ Are you aware of the term/word "Halal pharmaceuticals"? } & General practioner & 161 & 213.38 & 34354.00 & 17810.000 & -2.141 & $.032^{*}$ \\
\hline & Hospital doctor & 243 & 195.29 & 47456.00 & & & \\
\hline \multirow[t]{2}{*}{ Do you know that Muslim patients need Halal medicines? } & General practioner & 159 & 198.92 & 31628.50 & 18908.500 & -.562 & .574 \\
\hline & Hospital doctor & 241 & 201.54 & 48571.50 & & & \\
\hline Do you know that dead animals, blood, pork and Alcohol are & General practioner & 161 & 202.24 & 32560.00 & 19443.000 & -.083 & .934 \\
\hline Haram for Muslims to use in any form (food, medication etc)? & Hospital doctor & 242 & 201.84 & 48846.00 & & & \\
\hline \multirow{2}{*}{$\begin{array}{l}\text { Do you know that ingredients of some drugs/medicines are } \\
\text { derived from porcine and dead animals? }\end{array}$} & General practioner & 161 & 197.43 & 31787.00 & 18746.000 & -1.701 & .089 \\
\hline & Hospital doctor & 243 & 205.86 & 50023.00 & & & \\
\hline \multirow{2}{*}{$\begin{array}{l}\text { Do you know that resources are available to offer Halal } \\
\text { alternatives of non Halal drugs? }\end{array}$} & General practioner & 160 & 197.60 & 31615.50 & 18735.500 & -.610 & .542 \\
\hline & Hospital doctor & 241 & 203.26 & 48985.50 & & & \\
\hline \multirow{2}{*}{$\begin{array}{l}\text { Do you know that it is ethical obligation for a practitioner to take } \\
\text { consent from the patient before prescribing any medicine which } \\
\text { has any non-Halal content? }\end{array}$} & General practioner & 159 & 186.58 & 29667.00 & 16947.000 & -2.895 & $.004^{*}$ \\
\hline & Hospital doctor & 243 & 211.26 & 51336.00 & & & \\
\hline \multirow{2}{*}{$\begin{array}{l}\text { Do you know that most of the doctors are aware of the presence of } \\
\text { potentially forbidden animal-derived ingredients in medicines? }\end{array}$} & General practioner & 160 & 201.76 & 32282.00 & 19318.000 & -.050 & .960 \\
\hline & Hospital doctor & 242 & 201.33 & 48721.00 & & & \\
\hline
\end{tabular}

Table 2: Comparing attitude among general practioners and hospital doctors.

\begin{tabular}{|c|c|c|c|c|c|c|c|}
\hline Statements & Position & $\mathbf{N}$ & $\begin{array}{l}\text { Mean } \\
\text { Rank }\end{array}$ & $\begin{array}{c}\text { Sum of } \\
\text { ranks }\end{array}$ & $\begin{array}{c}\text { Mann- } \\
\text { Whitney U }\end{array}$ & $\mathbf{z}$ & $\mathbf{p}$ \\
\hline \multirow{2}{*}{$\begin{array}{l}\text { I discuss with patients about forbidden/Haram ingredients of } \\
\text { drugs. }\end{array}$} & General practioner & 161 & 183.28 & 29507.50 & \multirow{2}{*}{16466.500} & \multirow[t]{2}{*}{-2.964} & \multirow[t]{2}{*}{$.003^{*}$} \\
\hline & Hospital doctor & 244 & 216.01 & 52707.50 & & & \\
\hline \multirow{2}{*}{$\begin{array}{l}\text { I feel moral obligation to disclose the exact source of non-Halal } \\
\text { ingredients to the patient (e.g alcohol in syrups/elixirs and gelatin } \\
\text { in capsules). }\end{array}$} & General practioner & 161 & 203.79 & 32810.50 & \multirow[t]{2}{*}{19514.500} & \multirow[t]{2}{*}{-.120} & \multirow[t]{2}{*}{.904} \\
\hline & Hospital doctor & 244 & 202.48 & 49404.50 & & & \\
\hline \multirow[t]{2}{*}{ I take consent from patients, if I know the drug is non-Halal. } & General practioner & 157 & 197.35 & 30984.50 & \multirow[t]{2}{*}{18581.500} & \multirow[t]{2}{*}{-.536} & \multirow[t]{2}{*}{.592} \\
\hline & Hospital doctor & 244 & 203.35 & 49616.50 & & & \\
\hline \multirow{2}{*}{$\begin{array}{l}\text { I consider patient's religious beliefs when designing a treatment } \\
\text { regimen. }\end{array}$} & General practioner & 161 & 217.44 & 35007.50 & \multirow[t]{2}{*}{17317.500} & \multirow[t]{2}{*}{-2.188} & \multirow[t]{2}{*}{.029} \\
\hline & Hospital doctor & 244 & 193.47 & 47207.50 & & & \\
\hline \multirow[t]{2}{*}{ I make an effort to search for any available Halal alternatives. } & General practioner & 161 & 215.21 & 34649.50 & \multirow[t]{2}{*}{17514.500} & \multirow[t]{2}{*}{-1.892} & \multirow[t]{2}{*}{.059} \\
\hline & Hospital doctor & 243 & 194.08 & 47160.50 & & & \\
\hline \multirow[t]{2}{*}{ I educate the patient regarding Halal ingredients. } & General practioner & 161 & 202.07 & 32533.00 & \multirow[t]{2}{*}{19492.000} & \multirow[t]{2}{*}{-.138} & \multirow[t]{2}{*}{.890} \\
\hline & Hospital doctor & 244 & 203.61 & 49682.00 & & & \\
\hline \multirow[t]{2}{*}{ I prefer Halal medicines in my practice. } & General practioner & 160 & 223.05 & 35688.50 & \multirow[t]{2}{*}{16231.500} & \multirow[t]{2}{*}{-2.998} & \multirow[t]{2}{*}{$.003^{*}$} \\
\hline & Hospital doctor & 244 & 189.02 & 46121.50 & & & \\
\hline \multirow{2}{*}{$\begin{array}{l}\text { I recommend the purchase of Halal alternatives, which may be } \\
\text { more expensive. }\end{array}$} & General practioner & 161 & 218.98 & 35256.50 & \multirow[t]{2}{*}{17068.500} & \multirow[t]{2}{*}{-2.335} & \multirow[t]{2}{*}{$.020^{*}$} \\
\hline & Hospital doctor & 244 & 192.45 & 46958.50 & & & \\
\hline \multirow{2}{*}{$\begin{array}{l}\text { I feel that medical representatives are a good source of } \\
\text { information about sources \&ingredients of drugs for me. }\end{array}$} & General practioner & 160 & 212.47 & 33995.00 & \multirow{2}{*}{17765.000} & \multirow[t]{2}{*}{-1.553} & \multirow[t]{2}{*}{.120} \\
\hline & Hospital doctor & 243 & 195.11 & 47411.00 & & & \\
\hline
\end{tabular}

${ }^{*} \mathrm{P}$ value $\leq 0.05$ is significant

Table 3: Comparing perception among general practioners and hospital doctors.

\begin{tabular}{|c|c|c|c|c|c|c|c|}
\hline Statements & Position & $\mathbf{N}$ & $\begin{array}{l}\text { Mean } \\
\text { Rank }\end{array}$ & $\begin{array}{c}\text { Sum of } \\
\text { ranks }\end{array}$ & $\begin{array}{c}\text { Mann- } \\
\text { Whitney U }\end{array}$ & $\mathbf{z}$ & p \\
\hline \multirow{2}{*}{$\begin{array}{l}\text { Patient has a right to ask information about sources \& ingredients } \\
\text { of medicines. }\end{array}$} & General practioner & 162 & 218.02 & 35319.00 & \multirow[t]{2}{*}{17412.000} & \multirow[t]{2}{*}{-2.364} & \multirow[t]{2}{*}{$.018^{*}$} \\
\hline & Hospital doctor & 244 & 193.86 & 47302.00 & & & \\
\hline \multirow{2}{*}{$\begin{array}{l}\text { It is important for prescriber to explain about the sources \& } \\
\text { ingredients of medicine as maximum as possible and encourage } \\
\text { the patients to ask questions. }\end{array}$} & General practioner & 162 & 188.66 & 30563.00 & \multirow[t]{2}{*}{17360.000} & \multirow[t]{2}{*}{-2.210} & \multirow[t]{2}{*}{$.027^{*}$} \\
\hline & Hospital doctor & 243 & 212.56 & 51652.00 & & & \\
\hline \multirow{2}{*}{$\begin{array}{l}\text { It is not a common practice to inform the patients about sources of } \\
\text { the medicines. }\end{array}$} & General practioner & 160 & 224.97 & 35994.50 & \multirow[t]{2}{*}{15925.500} & \multirow[t]{2}{*}{-3.333} & \multirow[t]{2}{*}{$.001^{*}$} \\
\hline & Hospital doctor & 244 & 187.77 & 45815.50 & & & \\
\hline \multirow{2}{*}{$\begin{array}{l}\text { Drug manufacturers should provide prescribers with a list of their } \\
\text { products containing animal-derived ingredients }\end{array}$} & General practioner & 162 & 222.52 & 36047.50 & \multirow[t]{2}{*}{16521.500} & \multirow[t]{2}{*}{-3.070} & \multirow[t]{2}{*}{$.002^{*}$} \\
\hline & Hospital doctor & 243 & 189.99 & 46167.50 & & & \\
\hline \multirow{2}{*}{ Doctors should be educated about the sources of medicines. } & General practioner & 160 & 210.09 & 33614.00 & \multirow[t]{2}{*}{18306.000} & \multirow[t]{2}{*}{-1.181} & \multirow[t]{2}{*}{.238} \\
\hline & Hospital doctor & 244 & 197.52 & 48196.00 & & & \\
\hline \multirow{2}{*}{$\begin{array}{l}\text { Patient's religious beliefs need to be considered while prescribing } \\
\text { medicines. }\end{array}$} & General practioner & 162 & 217.89 & 35298.50 & \multirow[t]{2}{*}{17108.500} & \multirow[t]{2}{*}{-2.397} & \multirow[t]{2}{*}{$.017^{*}$} \\
\hline & Hospital doctor & 242 & 192.20 & 46511.50 & & & \\
\hline \multirow[t]{2}{*}{ Patient's religious beliefs } & General practioner & 161 & 211.19 & 34001.00 & \multirow[t]{2}{*}{18324.000} & \multirow[t]{2}{*}{-1.249} & \multirow[t]{2}{*}{.212} \\
\hline & Hospital doctor & 244 & 197.60 & 48214.00 & & & \\
\hline \multirow{2}{*}{$\begin{array}{l}\text { Pharmaceutical manufacturers should be sensitive towards the } \\
\text { requirement of patients and where ever possible should produce } \\
\text { Halal medicines. }\end{array}$} & General practioner & 162 & 228.96 & 37091.50 & \multirow[t]{2}{*}{15639.500} & \multirow[t]{2}{*}{-3.893} & \multirow[t]{2}{*}{$.000^{*}$} \\
\hline & Hospital doctor & 244 & 186.60 & 45529.50 & & & \\
\hline \multirow{2}{*}{$\begin{array}{l}\text { Drug companies should clearly mark medication packaging with } \\
\text { easy-to-spotHalal/non halal labels. }\end{array}$} & General practioner & 162 & 225.33 & 36503.00 & \multirow[t]{2}{*}{16228.000} & -3.376 & $.001^{*}$ \\
\hline & Hospital doctor & 244 & 189.01 & 46118.00 & & & \\
\hline Clear and well explained guidelines are need of the healthcare & General practioner & 161 & 215.60 & 34712.00 & 17613.000 & -1.940 & .052 \\
\hline professionalsto navigate religious conflicts. & Hospital doctor & 244 & 194.68 & 47503.00 & & & \\
\hline Healthcare professionals need to define medical necessity and & General practioner & 162 & 209.99 & 34018.00 & 18713.000 & -.990 & .322 \\
\hline explore existence of Halal alternatives. & Hospital doctor & 244 & 199.19 & 48603.00 & & & \\
\hline
\end{tabular}


Table 4: Comparison of KAP scores between general practioners and hospital doctors.

\begin{tabular}{|c|c|c|c|c|c|c|c|}
\hline Variable & Position & $\mathbf{N}$ & Median & $\begin{array}{l}\text { Mean } \\
\text { Rank }\end{array}$ & $\mathbf{U} *$ & $\mathbf{z}$ & $\mathrm{p}$ \\
\hline \multirow[t]{2}{*}{ Knowledge total score } & General practioner & 161 & 8 & 205.08 & 19306.500 & -.307 & .759 \\
\hline & Hospital doctor & 244 & 8 & 201.62 & & & \\
\hline \multirow[t]{2}{*}{ Attitude total score } & General practioner & 162 & 48 & 209.40 & 18808.500 & -.827 & .408 \\
\hline & Hospital doctor & 244 & 45 & 199.58 & & & \\
\hline \multirow[t]{2}{*}{ Perception total score } & General practioner & 162 & 35 & 221.85 & 16790.500 & -2.575 & .010 \\
\hline & Hospital doctor & 244 & 34 & 191.31 & & & \\
\hline
\end{tabular}

* Mann-Whitney U, Note: $\mathrm{N}$ =observed values; missing values are excluded

\section{CONCLUSION}

It can be concluded that there is significant difference in the knowledge and attitude of general practitioners and doctors working in hospitals, in some areas, while are equally aware and have same attitude in other areas. It is further concluded that significant difference is found in perception of general practitioners and doctors working in hospitals.

\section{REFERENCES}

Al-Quran Chapter 2 verse 168, Quran Explorer .Availablefrom: http://www.quranexplorer.com/quran/ [Last accessed on 2012 March 2].

Al-Quran Chapter 2 verse 173, Quran Explorer. Available from: http://www.quranexplorer.com/quran/ [Last accessed on 2012 March 2].

Al-Quran Chapter 5 verse 3, Quran Explorer. Available from: http://www.quranexplorer.com/quran/ [Last accessed on 2012 March 2].

Bjertnaes OA, Garratt A, Nessac J. The GPs experiences Questionnaire (GPEQ) Reliability and validity followingnational survey to assess GPs views of district psychiatricservices. Family Pract 2007; 24: $336-42$.

Cohen \&Kohler ,2007.The morally uncomfortable global drug gap. Clin Pharmacol Ther., 82(5), 610- 614

De Bourdeaudhuij I, Klepp K, Due P, Rodrigo C P, De Almeida M, Wind M, Krolner R, Sandvik C \& Brug J. Reliability and validity of a questionnaire to measure personal, social and environmental correlates of fruit and vegetable intake in 10-11-year-old children in five European countries. Public Health Nutrition-Wallingford, 2005; 8, 189-200.

Desai C K, lyer G, Panchal J, Shah S, \& Dikshit R K : An evaluation of knowledge, attitude and practice of adverse drug reactions reporting among prescribers in a tertiary care hospital. Perspectives in Clinical research, 2011; 2(4):129-136.

Easterbrook C and G Maddern, 'Porcine and Bovine Surgical Products: Jewish, Muslim, and Hindu Perspectives', Archives of Surgery, $2008 ; 143,366$

Geraldine M, Ghalamkari H, Beaumont S, Powell S, \& McGee, P, 2004. Informed Choice In Medicine Taking: Drugs of Porcine Origin \& Clinical Alternatives Medicines Partnership. London.

Hoesli T M, \& Smith K M. Effects of Religious and Personal Beliefs on Medication Regimen Design, Orthopedics, 2011; 34(4), 292.
Husain R, Ghani I A, Mohammad A F \& Mehad S. Current Practices among Halal Cosmetics Manufacturers in Malaysia. Journal of Statistical Modeling and Analytic, 2012; 3(1), 46-51.

Ismail N A, \& Abidin A Z. Perception towards the importance and knowledge of information technology among auditors in Malaysia. Journal of Accounting and Taxation, 2009; 1(4), 061-069.

Lie D A, \& Boker J. Comparative survey of Complementary and Alternative Medicine (CAM) attitudes, use, and information-seeking behaviour among medical students,residents \& faculty. BMC Medical Education, 2006; 6(58).

McCrum-Gardner E. Sample size and power calculations made simple. International Journal of Therapy and Rehabilitation, 2010; 17(1), $10-14$.

MS 1500: 2004 Requirements for Production of Halal Food. Nasaruddin R R, Fuad F, Jaswir I, Abd.Hamid H, \& Mel M.The Importance of a Standardized Islamic Manufacturing for Food and Pharmaceutical Productions. Advances in Natural and Applied Sciences, 2012; 6(5): 588-595.

Oshikoya K A \& Awobusuyi J O: Perceptions of doctors to adverse drug reaction reporting in a teaching hospital in Lagos, Nigeria BMC Clinical Pharmacology 2009, 9(14): doi: 10.1186/1472-6904-9-14.

Pallant J, 2011. SPSS Survival Manual: A Step by Step Guide to data Analysis Using SPSS. Sydney: Allen and Unwin. .

Population and Housing Census, population distribution and basic demographic characteristic report 2010, Dept. of Statistics Malaysia.

Rezaee Z, \& Burton E J. Forensic accounting education: insights from academicians and certified fraud examiner practitioners. Managerial Auditing Journal, 1997; 12(9), 479 - 489.

Riaz M N, Chaudry M M, 2004. Halal Food Production, Florida: CRC Press, Boca Raton.

Tiralongo E, \& Wallis M. Attitudes and perceptions of Australian pharmacy students towards Complementary and Alternative Medicine. BMC Complementary and Alternative Medicine 2008, 8(2).

Wong J J, Loreto L D, Kara A, Yu K, Mattia A, Soave D, Kopansky D. Assessing the attitudes, knowledge and perspectives of medical students to chiropractic. J Can Chiro pr Assoc, 2013; 57(1), 18 31.

\section{How to cite this article:}

Saleha Sadeeqa, Azmi Sarriff. Comparing KAP Regarding Halal Pharmaceuticals Among General Practitioners and Hospital Doctors. J App Pharm Sci, 2014; 4 (10): 092-096. 